\title{
ANALISIS MODEL KELEMBAGAAN BADAN PERTIMBANGAN TABUNGAN PERUMAHAN PEGAWAI NEGERI SIPIL (BAPERTARUM-PNS)
}

\author{
Muhammad Yuda Alhabsyi \\ Staf Pengajar Fakultas Ekonomi Universitas Pamulang \\ Email: boby_blue_99@yahoo.com
}

\begin{abstract}
Abstrak
Tujuan dari penelitian ini adalah merumuskan model kelembagaan BAPERTARUM-PNS tersebut realistis dan juga kompetensi dan sumberdaya pendukung dan penunjangnya memadai untuk menunjang model kelembagaan bagi BAPERTARUM-PNS. Metode penelitian yang digunakan adalah metode deskriptif, pengumpulan data dilakukan melalui wawancara, diskusi, observasi dan studi dokumentasi dan studi pustaka. Rancangan uji data digunakan analisis deskriptif dan analisis SWOT.Hasil dari penelitian ini menunjukkan bahwa:Terbukti bahwa analisis model kelembagaan BAPERTARUMPNS tersebut realistis.Permasalahan dari aspek hukum dengan diversifikasi strategi melalui penetapan status hukum kelembagaan BAPERTARUM-PNS pada dasarnya agar lembaga tersebut dapat secara otonom melakukan hak dan kewajiban sebagai subyek hukum (subjectum juris) dalam pergaulan hukum, baik secara nasional maupun internasional.Penelitian ini menyarankan agar menjadikan BAPERTARUM-PNS sebagai Badan Hukum Milik Negara (BHMN) karena memiliki kualifikasi yang tepat untuk menjaga kepentingan Pegawai Negeri Sipil sekaligus berperilaku sebagai korporat.
\end{abstract}

Kata kunci:Model Kelembagaan BAPERTARUM-PNS.

\begin{abstract}
:
The purpose of this research is to formulate the institutional model of BAPERTARUMPNS is realistic and also the competence and supporting and supporting resources are adequate to support institutional model for BAPERTARUM-PNS. The research method used is descriptive method, data collection is done through interview, discussion, observation and documentation study and literature study. The design of the test data used descriptive analysis and SWOT analysis.The results of this study indicate that:It is proven that the institutional model analysis of BAPERTARUM-PNS is realistic. Because at this time institutional BAPERTARUM-PNS is in a steady condition organically, but to face the problems that will come according to the development of the situation and the economy continues to increase Proven competence and supporting and supporting resources are sufficient to support institutional model for BAPERTARUM-PNS. both nationally and internationally.This research recommends to makeBAPERTARUM-PNS as Badan Hukum Milik Negara(BHMN) because it has the right qualification to keep the interest of Civil Servant as well as behave as a corporation.
\end{abstract}

Keywords :Institutional Model of BAPERTARUM-PNS 


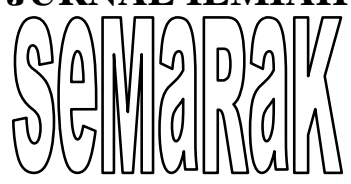

\section{PENDAHULUAN}

Menurut Syahyuti kelembagaan adalah sekumpulan jaringan dari relasi sosial yang melibatkan orang-orang tertentu, memiliki tujuan tertentu, memiliki aturan dan norma, serta memiliki struktur. Kelembagaan dapat berbentuk sebuah relasi sosial yang melembaga (non formal institution), atau dapat berupa lembaga dengan struktur dan badan hukum (formal institution). Lalu, lembaga atau dapat juga disebut 'organisasi', adalah bentuk kelembagaan yang formal, dengan ciri memiliki struktur yang tegas dan diformalkan. Lembaga menjalankan fungsi kelembagaan, namun dapat satu atau lebih fungsi sekaligus.

Dalam penyaluran dana Taperum-PNS, Pelaksana Sekretariat Tetap BAPERTARUM-PNS mempunyai 3 (tiga) fungsi layanan, yaitu:

1) Membantu uang muka (BUM) pembelian rumah dengan fasilitas KPR bagi PNS yang belum memiliki rumah.

2) Membantu sebagian biaya membangun (BM) rumah bagi PNS yang sudah memiliki tanah di daerah tempat bekerja.

3) Mengembalikan tabungan (PT) kepada PNS yang tidak memanfaatkan bantuan maupun pensiun.

\section{BAPERTARUM-PNS}

mempunyai visi menjadi pengelola Taperum-PNS yang bereputasi baik dan dipercaya serta handal dalam pemupukan dan pengelolaan dana perumahan serta mempunyai misi memberikan kemampuan kepada Pegawai Negeri Sipil dan kepada masyarakat yang berpenghasilan tetap dalam pemilikan rumah yang layak melalui bantuan pembiayaan dari dana tabungan perumahan Pegawai Negeri Sipil. Selain itu yang melatar belakangi didirikannya

BAPERTARUM-PNS, antara lain :

1) Sebagai upaya untuk meningkatkan kesejahteraan Pegawai Negeri Sipil untuk memiliki rumah yang layak.

2) Terbatasnya kemampuan Pegawai Negeri Sipil untuk membayar uang muka pembelian rumah dengan fasilitas Kredit Kepemilikan Rumah atau KPR.

3) Tabungan perumahan Pegawai Negeri Sipil dapat membentuk dana untuk mengatasi kendala tersebut yang merupakan kegotongroyongan diantara Pegawai Negeri Sipil dalam upaya peningkatan kesejahteraan antara Pegawai Negeri Sipil.

Berdasarkan data-data dan kondisi yang penulis lihat di lapangan, penulis merasa tertarik untuk mengkaji lebih jauh dan menjadi sangat penting untuk menganalisis model kelembagaan kantor Bapertarum-PNS. Sehingga penelitian ini diberi judul Analisis

\section{Model Kelembagaan Badan} Pertimbangan Tabungan Perumahan Pegawai Negeri Sipil (BAPERTARUM-PNS).

\section{TINJAUAN PUSTAKA DAN KERANGKA PEMIKIRAN}

\section{A. Deskripsi Teoritik}

1. Pengertian Manajemen

Menurut G.R. Terry (2010:16) manajemen adalah suatu proses atau kerangka kerja, yang melibatkan bimbingan atau pengarahan suatu kelompok orang-orang kearah tujuan-tujuan organisasional atau maksudmaksud yang nyata. Manajemen juga adalah suatu ilmu pengetahuan maupun seni. Seni adalah suatu pengetahuan bagaimana mencapai hasil yang diinginkan atau dalam kata lain seni adalah kecakapan yang diperoleh dari pengalaman, 


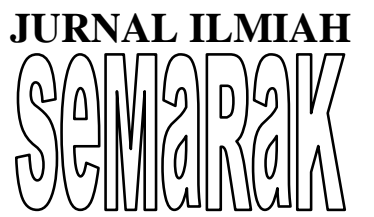

pengamatan dan pelajaran serta kemampuan menggunakan manajemen.

Menurut Mary Parker Follet dalam Handoko (2000:8) manajemen merupakan seni dalam menyelesaikan pekerjaan melalui orang lain. Definisi ini mengandung arti bahwa para manajer mencapai tujuan-tujuan organisasi melalui pengaturan orang-orang lain untuk melaksanakan berbagai tugas yang mungkin diperlukan, atau dengan kata lain dengan tidak melakukan pekerjaan-pekerjaan itu sendiri. atau dengan kata lain dengan tidak melakukan pekerjaan-pekerjaan itu sendiri.

Itulah manajemen, tetapi menurut Stoner bukan hanya itu saja.Masih banyak lagi sehingga tak ada satu definisi saja yang dapat diterima secara universal. Menurut James A.F. Stoner, manajemen adalah suatu proses perencanaan, pengorganisasian, kepemimpinan dan pengendalian upaya anggota organisasi dan menggunakan semua sumber daya organisasi untuk mencapai tujuan yang telah ditetapkan.

2. Manajemen Sumber Daya Manusia

Menurut Hasibuan (2010:22), manajemen sumber daya manusia adalah ilmu dan seni mengatur hubungan dan peranan tenaga kerja agar efektif dan efisien membantu terwujudnya tujuan perusahaan, karyawan, dan masyarakat. Menurut Simamora (2006:5), manajemen sumber daya manusia adalah pendayagunaan, pengembangan, penilaian, pemberian balas jasa, dan pengelolaan individu anggota organisasi atau kelompok pekerja.

Menurut Gary Dessler, manajemen sumber daya manusia adalah kebijakan dan praktik yang dibutuhkan seseorang untuk menjalankan aspek "orang" atau sumber daya manusia dari posisi seorang manajemen, meliputi perekrutan, penyaringan, pelatihan, pengimbalan dan penilaian. Sedangkan menurut T. Hani Handoko (2011:3), manajemen sumber daya manusia adalah penarikan, seleksi, pengembangan, pemeliharaan dan penggunaan sumber daya manusia untuk mencapai baik tujuan-tujuan individu maupun organisasi.

Dari penjelasan di atas dapat disimpulkan bahwa manajemen sumber daya manusia mempunyai definisi sebagai suatu perencanaan, pengorganisasian, pengarahan, dan pengawasan atas pengadaan, pengembangan, kompensasi, pengintegrasian, pemeliharaan, dan pemutusan hubungan kerja dengan maksud untuk mencapai tujuan organisasi perusahaan secara terpadu.

Untuk memenuhi kebutuhan Sumber Daya Manusia yang berkualitas, BAPERTARUM-PNS

melakukannya sejak proses rekrutmen. Penambahan pegawai baru dilakukan melalui proses seleksi yang ketat dengan melihat latar belakang pendidikan dan pengalamannya. Sampai dengan bulan Desember 2012 jumlah karyawan BAPERTARUM-PNS 73 orang terdiri dari 49 orang laki-laki dan 24 orang perempuan, dari 


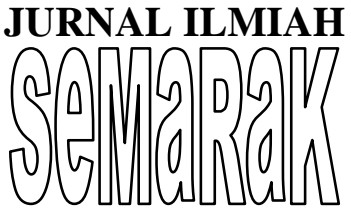

73 karyawan, sekitar $80 \%$ nya memiliki latar belakang pendidikan dari perguruan tinggi.

3. Model Kelembagaan

Pembangunan Lembaga merupakan salah satu perspektif tentang perubahan sosial yang direncanakan dan dibina, serta berkaitan dengan inovasiinovasi yang berorientasi pada perubahan sosial yang dilakukan melalui organisasi formal.Tujuannya adalah untuk membangun organisasi yang dapat hidup dan efektif serta dapat mendukung inovasi sebagai perubahan sosial. Proses yang terjadi dalam Pembangunan Lembaga ini bersifat generik. Dimana inovasi sosial ini tidak dipaksakan dalam tiap sektor masyarakat. Sehingga dalam model Pembangunan Lembaga ini, lembaga ditempatkan sebagai organisasi formal yang menghasilkan perubahan, dan melindungi perubahan serta jaringannya.

Salah satu lembaga yang dimiliki oleh pemerintah Indonesia adalah Badan Pertimbangan Tabungan Perumahan Pegawai Negeri Sipil yang disingkat BAPERTARUM-PNS. Yaitu institusi yang diberi mandate untuk menyalurkan dana tabungan perumahan pegawai negeri sipil yang disingkat Taperum-PNS.

Badan Pertimbangan Tabungan Perumahan Pegawai Negeri Sipil (BAPERTARUMPNS) dibentuk berdasarkan Keputusan Presiden Republik Indonesia Nomor : 14 Tahun 1993 tentang Tabungan Perumahan Pegawai Negeri
Sipil jo. Keputusan Presiden Republik Indonesia Nomor : 46 Tahun 1994 tentang Perubahan Atas Keputusan Presiden Republik Indonesia Nomor : 14 Tahun 1993 dengan tujuan untuk mengelola Tabungan Perumahan Pegawai Negeri Sipil (Taperum-PNS).

\section{Reformasi Kelembagaan}

Reformasi birokrasi pada hakikatnya merupakan upaya untuk melakukan pembaharuan dan perubahan mendasar terhadap system penyelenggaraan pemerintahan terutama menyangkut aspekaspek kelembagaan (organisasi), ketatalaksanaan (business process) dan sumber daya manusia aparatur.

Reformasi birokrasi di Indonesia menempatkan pentingnya rasionalisasi birokrasi yang menciptakan efisiensi, efektivitas, dan produktifitas melalui pembagian kerja hirarkikal dan horizontal yang seimbang, diukur dengan rasio antara volume atau beban tugas dengan jumlah sumber daya disertai tata kerja formalistic dan pengawasan yang ketat.

Penataan organisasi pemerintah baik pusat maupun daerah didasarkan pada visi, misi dan sasaran strategis, agenda kebijakan, program dan kinerja kegiatan yang terencana dan diarahkan terbangunnya sosok birokrasi dengan tugas dan pertanggungjawaban terbuka dan aksessif.Penyederhanaan tata kerja dalam hubungan intra dan antar aparatur serta antar aparatur dengan masyarakat dan dunia usaha yang berorientasi pada kriteria dan mekanisme 


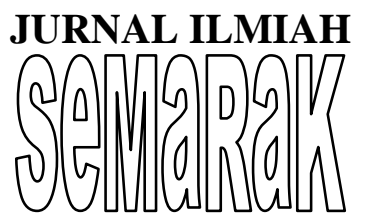

yang impersonal terarah pada penerapan pelayanan prima. pemerintahan.Globalisasi

tak lepas dari kompetisi dunia global yang makin keras, yang mensyaratkan peningkatan daya saing.Pemerintah dituntut untuk memberikan pelayanan yang lebih baik kepada setiap stakeholder nya.Efisiensi menjadi penting.Terminologi "Better, Cheaper, Faster, Easier" pun menjadi jargon utama.Efisiensi dalam pelayanan menjadi modal utama guna memenangkan kompetisi tersebut, utamanya dalam menggaet investor.

5. Penyebab Lemahnya Kinerja Pelayanan Publik

Salah satu penyebab lemahnya kinerja pelayanan publik terjadi karena birokrasi kita tenggelam dalam paradigma pelayanan yang mereka buat sendiri, yang justru cenderung mengabaikan aspirasi publik sebagai obyek pelayanan itu sendiri.Padahal, belum optimalnya peran pemerintah dalam memberikan pelayanan yang paripurna berakibat pada minimnya partisipasi masyarakat dalam pembangunan.Selain itu, kemiskinan yang terus melembaga juga tak dapat dilepaskan dari terhambatnya akses pelayanan yang seharusnya ikut dinikmati dan dimanfaatkan oleh warga yang berdiam di kantong-kantong kemiskinan, papar Alisjahbana.Ada 4 hal yang menyebabkan lemahnya kinerja pelayanan publik.

a. Masalah kelembagaan dan manajemen pelayanan. b. Masalah profesionalisme dalam sikap, managerial, teknis dan administratif.

c. Masalah keuangan pemerintah.

d. Masalah radius pelayanan.

6. Pembaruan Birokrasi Alisjahbana juga mengatakan, empat masalah penyebab lemahnya kinerja pelayanan publik dapat diantisipasi melalui reaktualisasi pemerintahan, utamanya di tingkat daerah, dengan strategi penguatan pemerintah daerah yang tepat. Strategi penguatan tersebut bermanfaat dalam mempercepat proses sustainabilitas pemerintah daerah itu sendiri, yang mengurangi ketergantungan daerah pada bantuan dari pemerintah pusat maupun propinsi. Strategi ini dijalankan melalui reaktualisasi kewenangan daerah, restrukturisasi kelembagaan pemerintah, reposisi dan relokasi personil yang cermat, penataan manajemen keuangan, pemberdayaan DPRD sebagai fungsi kontrol eksekutif, dan perbaikan manajemen pelayanan.

\begin{tabular}{lr}
\multicolumn{1}{c}{ Dalam } & kerangka \\
demikian, & perampingan \\
kelembagaan & pemerintah
\end{tabular}
menjadi keniscayaan, meskipun reformasi kelembagaan itu bukan pekerjaan mudah.Sebagai langkah awal, pemerintah perlu melakukan evaluasi kelembagaan berdasarkan tugastugas yang diemban oleh dinasdinas terkait.Evaluasi ini diarahkan untuk melihat permasalahan yang muncul dalam pelaksanaan tugas kelembagaan tersebut. Beberapa permasalahan itu di antaranya: pertama, adanya beberapa 


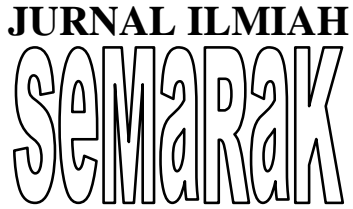

penugasan yang tumpang tindih, baik antar organisasi, maupun antara satuan tugas organisasi. Kedua, terdapat ketimpangan antara volume kerja dengan besaran struktur organisasi; ketiga, terdapat beberapa satuan organisasi yang kurang didukung oleh sumber daya (aparat, anggaran dan sarana) yang sesuai kebutuhan; dan keempat, koordinasi pelaksanaan tugas kurang optimal karena belum adanya mekanisme kerja yang baku.

Berangkat dari empat permasalahan tersebut, penataan kelembagaanyang

dikembangkan oleh pemerintah daerah harus diletakkan dalam kerangka peran pemerintah, yang terdiri atas fungsi pengaturan, pelayanan publik, dan pemberdayaan, guna meningkatkan profesionalitas lembaga dalam memberikan pelayanan kepada masyarakat.Penataan tersebut juga diwujudkan dalam model subsidiarity, di mana masyarkat dilibatkan secara aktif dalam penyelenggaraan pemerintahan.

$$
\text { Pada }
$$

akhirnya,

keseluruhan penataan

kelembagaan tersebut ditujukan untuk membangun organisasi pemerintah daerah yang fleksibel, tahan banting dan adjustable atas setiap perubahan situasi yang berkembang di masyarakat. Organisasi itu nantinya diharapkan memiliki kepekaan yang tinggi terhadap berbagai tantangan dan permasalahan yang muncul kemudian, sekaligus mampu melakukan lompatan ke depan untuk menjawab berbagai dinamika tersebut dan mewujudkan tata pemerintahan yang efektif, aspiratif dan efisien.

\section{B. Kerangka Berpikir}

Kerangka berpikir yang baik akan menjelaskan secara teoritis pertautan antara variabel yang akan diteliti. Jadi secara teoritis perlu dijelaskan hubungan antara variabel independen dan dependen.Bila dalam penelitian ada variabel moderator dan intervening, maka juga perlu dijelaskan, mengapa variabel itu ikut dilibatkan dalam penelitian.Oleh karena itu pada setiap penyusunan paradigma penelitian harus didasarkan pada kerangka berpikir.

Model Kelembagaan Badan Pertimbangan Tabungan Perumahan Pegawai Negeri Sipil dinilai tidak jelas sehingga diperlukan perubahan mendasar dalam rangka optimalisasi penyediaan perumahan bagi pelayan publik tersebut. Dana tabungan perumahan (Taperum) PNS berdasarkan definisi dan unsurunsur keuangan negara yang ditetapkan oleh UU No. 17/2003 tentang Keuangan Negara, tabungan perumahan PNS termasuk bagian dari keuangan negara. Oleh karena itu, keuangan negara harus dikelola secara tertib, ekonomis, efisien dan efektif, transparan, bertanggung jawab dan memperhatikan rasa keadilan dan kepatutan, akuntabilitas berorientasi pada hasil.

Berdasarkan peraturan tersebut, yang menjadi ketua adalah Presiden, sedangkan ketua harian dipangku oleh Menteri Perumahan Rakyat.Sementara anggota terdiri dari Menteri Keuangan, Menteri Dalam Negeri, Menteri Pendayagunaan Aparatur Negara serta Kepala Badan Kepegawaian Negara.Diperlukan perubahan dasar hukum pemungutan Taperum, dari 


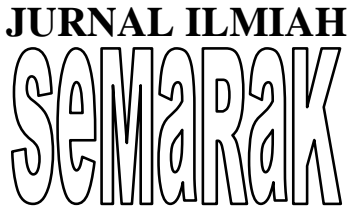

Keppres menjadi UU atau minimal Peraturan Pemerintah.

Untuk lembaga seperti Bapertarum-PNS harus ada Peraturan Presiden yang baru untuk mengganti Keputusan Presiden (Keppres) Nomor 14 tahun 1993 tentang Tabungan Perumahan Pegawai Negeri Sipil. Rancangan Peraturan Presiden tersebut terutama ditujukan untuk memperbaiki produk Taperum-PNS sehingga fasilitas tersebut menarik bagi Pegawai Negeri Sipil dan benarbenar dapat membantu pemenuhan kebutuhan perumahan. Mengenai pengelolaannya, perlu dilindungi regulasi selevel undang-undang (UU) atau peraturan pemerintah (PP). Tidak sekedar keputusan presiden (kepres) seperti implementasi saat ini.Peningkatan status regulasi itu agar pemungutan Taperum dari gaji PNS dapat diaplikasikan secara optimal, sistem organisasi dan akuntabilitasnya jelas, tertib administrasi, serta audit kontrolnya baik, sehingga berpengaruh juga terhadap kinerja pegawainya dan kepercayaan terhadap lembaga untuk kelangsungan karir kerja pegawai.

Berdasarkan uraian diatas maka kerangka pikir dapat penulis gambarkan melalui bagan alir pemikiran seperti pada gambar 2.1.Mulai dari Analisis Model Kelembagaan BAPERTARUM-PNS sebagai analisa awal dimulainya penelitian ini.Latar belakang penelitian yang meliputi 1).Mewujudkan Visi dan Misi organisasi; 2).Status hukum kelembagaan organisasi; 3).Kondisi keuangan dan asset organisasi yang semakin meningkat.

Tahapan selanjutnya teridentifikasi faktor-faktor yang terdiri atas faktor internal dan faktor eksternal, kedua faktor tersebut akan dianalisis menggunakan Matrik SWOT, hasilnya akan dipengaruhi oleh Sumber daya pendukung dan Sumber daya penunjang, untuk di analisa kelayakan nya. Bila layak maka akan di implementasikan kedalam Model Kelembagaan bagi BAPERTARUM-PNS.

\section{METODOLOGI PENELITIAN}

Metode penelitian yang penulis maksudkan dalam penelitian ini adalah prosedur atau cara yang digunakan untuk mengetahui, mempelajari dan mendapatkan data serta fakta-fakta sebagai jawaban dari masalah yang dipertanyakan, agar pelaksanaan penelitian dapat menghasilkan produk yang dapat dipertanggung jawabkan. Agar penelitian yang dilakukan dapat menjawab permasalahan penelitian yang diajukan, tentunya diperlukan penggunaan metode penelitian yang tepat sehingga penelitian dapat menggali data data yang dibutuhkan sesuai dengan topic penelitian.

\section{Untuk}

menjawab permasalahan yang sesuai dalam penelitian ini, análisis kualitatif terhadap data penelitian dianggap lebih sesuai dengan pertimbangan pertimbangan sebagai berikut :

1. Analisis kualitatif lebih adaptif dan lebih sesuai apabila menemukan masalah masalah yang lebih kompleks.

2. Analisis kualitatif lebih peka dan luwes

3. Peneliti terlibat langsung dalam permasalahan yang menjadi objek penelitian, dimungkinkan adanya hubungan antara responden dan peneliti.

Pendekatan kualitatif adalah suatu proses penelitian dan pemahaman yang berdasarkan pada metodologi yang menyelidiki suatu fenomena sosial dan masalah manusia. Pada pendekatan ini, peneliti membuat suatu gambaran 


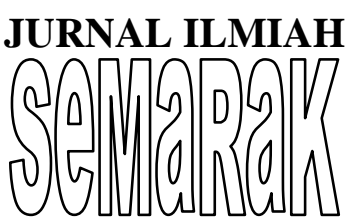

kompleks, menelit laporan terinci dari responden, atau melakukan wawancara dan diskusi dengan responden, dan melakukan studi pada situasi yang alami.Bogdan dan Taylor (Moleong, 2007:3) mengemukakan bahwa metodologi kualitatif merupakan prosedur penelitian yang menghasilkan data deskriptif berupa kata-kata tertulis maupun lisan dari orang-orang dan perilaku yang diamati.Sementara itu menurut Sugiyono (2000:10), metode deskriptif adalah jenis penelitian yang dilakukan terhadap variable mandiri. Artinya, tanpa membuat perbandingan atau menghubungkan dengan variable lain.

Penelitian kualitatif dilakukan pada kondisi alamiah dan bersifat penemuan.Dalam penelitian kualitatif, peneliti adalah instrumen kunci.Oleh karena itu, peneliti harus memiliki bekal teori dan wawasan yang luas jadi bisa bertanya, menganalisis, dan mengkonstruksi obyek yang diteliti menjadi lebih jelas.

Pelaksanaan penelitian meliputi proses membuat percobaan atau pengamatan serta memilih pengukuran-pengukuran variabel, memilih prosedur dan teknik sampling, alat-alat untuk mengumpulkan data kemudian membuat coding dan editing, serta memproses data yang telah dikumpulkan. Lalu dilakukan analisis data dengan analisis swotyaitu metode perencanaan strategis yang digunakan untuk mengevaluasi kekuatan (strengths), kelemahan (weaknesses), peluang (opportunities), dan ancaman (threats) dalam suatu provek atau suatu spekulasi bisnis. keempat faktor itulah yang membentuk akronim SWOT (Strengths,
Weaknesses, Opportunities, dan Threats).

\section{HASIL PENELITIAN DAN PEMBAHASAN}

Analisis

SWOT

membandingkan antara faktor eksternal Peluang dan Ancaman dan faktor internal Kekuatan dan Kelemahan. Setelah dilakukan pendekatan kualitatif matriks SWOT dan pendekatan kuantitatif analisis SWOT didapat hasil:

Rekapitulasi Nilai Tertimbang

Nilai Tertimbang Kekuatan

$=\quad 4,72$

Nilai Tertimbang Kelemahan

$=\frac{4,20-}{\text { Selisih Positif }(\mathrm{X})}$

$=\quad 0,52$

Nilai Tertimbang Opportunity

$$
=\quad 3,40
$$

Nilai Tertimbang Threat

$=\quad 4,24$ -

Selisih Negatif (Y)

$=\quad-0,84$

Berdasarkan matrik tersebut di atas, terlihat bahwa nilai kekuatan dibanding nilai kelemahan adalah sebesar 0,52. Sedangkan nilai peluang dibanding nilai tantangan adalah sebesar -0,84. Dari perhitungan nilai tertimbang tersebut, maka posisi strategi Badan Pertimbangan Tabungan Perumahan Pegawai Negeri Sipil (BAPERTARUM $\neg$ PNS) pada Matrik SWOT Empat Kuadran dapat digambarkan sebagai berikut:

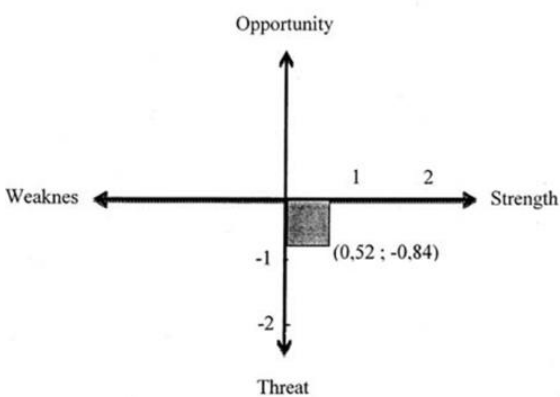




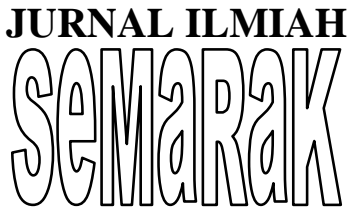

\section{Gambar Diagram Hasil Analisis} SWOT

Dengan nilai tertimbang faktor kekuatan-kelemahan positif sebesar 0,52 dan nilai tertimbang faktor peluang dan ancaman negatif sebesar -0,84 maka posisi strategi Badan Pertimbangan Tabungan Perumahan Pegawai Negeri Sipil (BAPERTARUM-PNS) pada matrik SWOT Empat Kuadran terletak pada Kuadran II (positif, negatif) dengan strategi "Diversifikasi Strategi". Artinya: Posisi ini menandakan sebuah organisasi yang kuat namun menghadapi tantangan yang besar. Rekomendasi strategi yang diberikan adalah Diversifikasi Strategi, yaitu organisasi dalam keadaan mantap namun menghadapi sejumlah tantangan berat sehingga diperkirakan roda organisasi akan mengalami kesulitan untuk terus berputar bila hanya bertumpu pada strategi sebelumnya. Oleh karenanya organisasi disarankan untuk segera memperbanyak ragam strategi taktisnya.

\section{KESIMPULAN DAN SARAN}

Berdasarkan hasil penelitian yang telah dilakukan, pembahasan dan uraian pada bab sebelumnya, maka dapat ditarik kesimpulan sebagai berikut,hasil dari penelitian ini menunjukkan bahwa:

Terbukti bahwa analisis model kelembagaan BAPERTARUM-PNS tersebut realistis. Karena pada saat ini kelembagaan BAPERTARUMPNS memang dalam kondisi yang mantap secara organisasi, akan tetapi untuk menghadapi masalah yang akan datang sesuai perkembangan situasi dan ekonomi yang terus meningkat, maka akan semakin berat jika hanya mengandalkan strategi yang ada saat ini pada lembaga ini.

Terbukti kompetensi dan sumberdaya pendukung dan penunjangnya memadai untuk menunjang model kelembagaan bagi BAPERTARUM-PNS. Permasalahan dari aspek hukum dengan diversifikasi strategi melalui penetapan status hukum kelembagaan BAPERTARUMPNS pada dasarnya agar lembaga tersebut dapat secara otonom melakukan hak dan kewajiban sebagai subyek hukum (subjectum juris) dalam pergaulan hukum, baik secara nasional maupun internasional.

Penelitian ini menyarankan agar menjadikan BAPERTARUMPNS sebagai Badan Hukum Milik Negara (BHMN) karena memiliki kualifikasi yang tepat untuk menjaga kepentingan Pegawai Negeri Sipil sekaligus berperilaku sebagai korporat. Bentuk Badan Hukum Milik Negara (BHMN) dipandang akan mampu membawa kemajuan BAPERTARUM-PNS kedepannya 
JURNAL ILMIAH

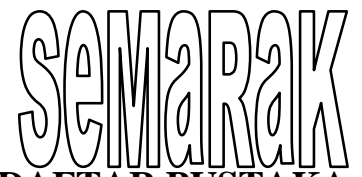

DAFTAR PUSTAKA

Buku:

Alisjahbana, Wirawan. I. B., 2008, Rumahku Impianku Humas BAPERTARUM-PNS, Jakarta

BAPERTARUM-PNS, 2003， 10 TAHUN Melayani Pegawai Negeri Sipil Melalui Tabungan Perumahan, PT. Pro Fajar, Jakarta

BAPERTARUM-PNS, Laporan Akhir Penyusunan Peraturan di Bidang Pengawasan , 2011, PT. Sugitek Patih Perkasa, Jakarta

Riduwan, 2011, Skala Pengukuran VariabelVariabel Penelitian, Alfabeta, Bandung

Sugiyono, 2007, Metode Penelitian Kuantitatif Kualitatif dan R\&D, Alfabeta, Bandung.

2009, Metode Penelitian Kuantitatif Kualitatif dan R\&D, Alfabeta, Bandung

Sulistyo, Joko. 2012, 6 hari jago SPSS 17, PT. Bhuana Ilmu Populer, Jakarta

Dokumen Lembaga:

Arsip Kantor BAPERTARUM-PNS, Wisma Iskandarsyah Blok C-3 Jl. Iskandarsyah raya Kay. $12-14$ Kebayoran barn Jakarta-Selatan

\section{Karya Akademis:}

Karimah, Akhlakul 2012.Evaluasi Program Bantuan Uang Muka (BUM) Kredit Pemilikan Rumah Bagi Pegawai Negeri Sipil Di DKI Jakarta. Skripsi FISIP Universitas Indonesia
Muttaqin, Subakti 2012.Analisis Kelayakan Pembukaan Tourist Information Centre di Kawasan Wisata Kotatua Untuk Pengembangan Dan Pelayanan Informasi Pariwisata Di Provinsi Jakarta. Tesis Manajemen Sumber Daya Manusia Universitas Pamulang.

\section{Peraturan Perundang Undangan:}

Keputusan Presiden Republik Indonesia Nomor : 14 Tahun 1993 tentang Tabungan Perumahan Pegawai Negeri Sipil

Keputusan Presiden Republik Indonesia Nomor : 46 Tahun 1994 tentang Perubahan Atas Keputusan Presiden Republik Indonesia Nomor : 14 Tahun 1993

Peraturan Pemerintah Republik Indonesia Nomor : 23 Tahun 2005 tentang Pengelolaan Keuangan Badan Layanan Umum

Undang-undang Republik Indonesia, Nomor 17 tahun 2003 Tentang Keuangan Negara

\section{Publikasi Elektronik:}

Aza, Shiryuu (2012), desain penelitian, April 09, 2013 http://akanksutha.blogspot.com/2012/03/desainpenelitian.html

Syahyuti (2007), Kelembagaan dan Lembaga dalam Pengembangan agribisnis Pedesaan, Desember 10, 2012 http://www.websyahyuti.blogspot.com/2 007/08/kelembagaan-dan-lembagadalam.html 


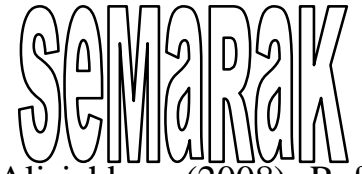

Alisjahbana (2008), ReformasiKelembagaan

Menuju EfisiensiPelayanan Pemerintah, November 15, 2012

http://www.2.alisjahbana08.wordpress.c om/2008/04/02/reformasi-kelembagaanmenuju-efisiensi-pelayanan-pemerintah/

Hirto, Sahrory (2012), Reformasi Birokrasi di Indonesia dalam Perspektif Perilaku, Oktober 07, 2012

http://www.birokrasi.kompasiana.com/2 011/10/04/reformasi-birokrasidiindonesia-398477.html

Afriani, Iyan H.S. (2009), Metode Penelitian Kualitatif, Desember 25, 2012

http ://www. penalaranunm.org/index.php/artikel-

nalar/penelitian/116- metode penelitiankualitatif.html

Cokroaminoto, (2010), Sumber Data Dalam Penelitian, Desember 25, 2012

http://www.cokroaminoto.blogetery.com /2010/02/18/sumber-data-dalam penelitian/

Wikipedia, (2010), Analisis SWOT, Februari 18, 2013

http://www.id.wikipedia.org/wiki/Analisi s SWOT

Wikipedia, (2011), Lembaga Negara, Januari 15, 2013

http://www.id.wikipedia.org/wiki/Lemba ga negara

Scribd.com, Pengertian manajemen, Maret 10, 2013

http://www.id.scribd.com/doc/4994224/p engertian-manajemen

Deviana, Kariana. (2012), Manajemen Sumber Daya manusia, Maret 10, 2013 http://www.karinadevianta.blogspot.com /2012/01/bab-10-manajemen-sumberdaya-manusia.html
Masaong, Kadim. Arfan A. Tilomi. 2011 Kepemimpinan berbasis multiple intelligence. Gorontalo: Alfabeta.

Nawawi, Hadari. 2006. Manajemen Sumber Daya Manusia untuk Bisnis yang Kompetitif. Yogyakarta: Gajah Mada University Press

Nurdin, Muhammad. 2010. Kita Menjadi Guru Profesional. Yogyakarta: Ar-ruzzmedia

Prabu Mangkunegara, Anwar. 2012. Evaluasi Kinerja SDM. Bandung: PT. Reflika Aditama

Robbins, P. Staphen. 2007. Manajemen. Jakarta: Indeks

Riduan. 2010. Metode dan Teknik Menyususn Penelitian. Bandung: Alfabeta

Sanusi, Anwar. 2011. Metodologi Penelitian Bisnis. Malang: Salemba Empat

Sedarmayanti. 2009. Sumber daya manusia an produktivitas kerja. Bandung: Mandar

Siagian, Sondang P. 2012. Manajemen Sumber Daya Manusia. Jakarta: Bumi Aksara

Silaen, Sakti. 2010. Statistik untuk Bisnis dan Ekonomi. Jakarta: PT Mitra Wacana Media

Siswanto, H.B. 2005. Pengantar Manajemen. Bandung: Bumi Aksara.

Subekhi, Akhmad dkk. 2012. Pengantar Manajemen Sumber Daya Manusia. Jakarta: PT Prestasi Pustakaraya 
JURNAL ILMIAH

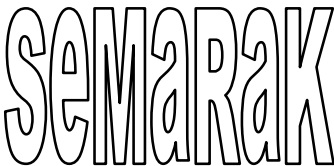

P-ISSN 2615-6849, E-ISSN 2622-3686

Jurnal Semarak,Vol. 2,No.1, Februari 2019, Hal (85-96)

@ Prodi Manajemen Fakultas Ekonomi Universitas Pamulang

Sunyoto, Danang. 2012. Manajemen Sumber

Daya Manusia. Yogyakarta: CAPS

Sugiyono. 2012. Metode Penelitian kuantitatif dan $R \& D$. Bnadung: CV. Alfabeta

Kombinasi. Bandung: Alfabeta

Sutrisno, Edi. 2009. Manajemen Sumber Daya Manusia. Jakarta: PT Kencana Prenada Media Group

Umam, Khaerul. 2010. Perilaku Organisasi. Bandung: CV Pustaka Setia 